Tersedia Secara Online di

\title{
Mengurangi Resiko Banjir Pada Sungai Bruno Kediri dengan Konstruksi Bendung
}

\author{
M. U. Reku ${ }^{1 *}$, Y. C. S. Poernomo ${ }^{2}$, S. Winarto ${ }^{3}$, A. Yamin ${ }^{4}$ \\ ${ }^{1 * 2,3}$ Fakultas Teknik, Universitas Kadiri. \\ Email: ${ }^{{ }^{*}}$ marlintoumbureku@gmail.com
}

\begin{tabular}{ll} 
A R T I C L E & I N F O \\
\hline Article history : & \\
Artikel masuk & $: 02-09-2021$ \\
Artikel revisi & $: 11-09-2021$ \\
Artikel diterima & $: 21-09-2021$ \\
\hline
\end{tabular}

Keywords :

Flood Risk, Flood, River, Water Resources.

\section{Style IEEE dalam mensitasi artikel ini: \\ [16] \\ C. Yohana, D. Griandini, and S. Muzambeq, "Penerapan Pembuatan Teknik Lubang Biopori Resapan Sebagai Upaya Pengendalian Banjir," J. Pemberdaya. Masy. Madani, vol. 1, no. 2, pp. 296-308, 2017, doi: 10.21009/jpmm.001.2.10.}

\begin{abstract}
A B S T R A C T
Flooding is a problem that needs to be considered because it affects all sectors. The Bruno River in Kediri Regency often experiences flooding in the rainy season, although the overflow does not reach the settlements. But already, some levees in the Bruno river broke because they could not accommodate the discharge from the Bruno river. Such characteristics have the potential to be the cause of flooding. The core of the problem arranges various flood control efforts. The development of complementary infrastructure such as Water Resources becomes the right choice to overcome the flood event. This research aims to plan Water Resources to control the flood on the Bruno river, Kediri Regency. The analysis includes hydrological analysis and hydraulic analysis. The hydrological analysis includes rainfall calculations, match tests, and flood plans, while hydraulic analysis includes the calculation of bend dimensions. Rainfall data were obtained from kanyoran rain station for the past 10 years. From the rainfall data is done calculations and compared with estimates when re-from related agencies. So, the difference in discharge is known that is used as the basis of the analysis of Water Resources planning. The results of the study obtained flood discharge of $69,20762609 \mathrm{~m}^{3} / \mathrm{s} . \approx 70 \mathrm{~m}^{3} / \mathrm{s}$ with a high bend planning bend $4.3 \mathrm{~m}$ wide $30 \mathrm{~m}$. The elevation of the water level downstream of the bend is $+51.56 \mathrm{~m}$ so that the planning results can be used as a step to reduce flooding in the Bruno river.
\end{abstract}

\section{Pendahuluan}

Banjir merupakan peristiwa tergenangnya suatu wilayah yang terjadi akibat meluapnya air pada sungai atau sistem penampungan [1][2]. Luapan air mengindikasikan bahwa telah terjadi curah hujan yang tinggi di atas normal yang menyebabkan saluran/sungai tidak mampu menampung debit air tersebut. Kerugian yang ditimbulkan akibat bencana banjir cukuplah besar, seperti kerusakan bangunan hingga timbulnya korban jiwa [3][4][5]. Sehingga, perlu adanya perhatian lebih khusus mengenai permasalahan tersebut. Pengelolaan banjir secara 
struktural maupun non struktural merupakan salah satu cara yang dapat dilakukan dalam meminimalisasi risiko yang timbul akibat banjir. Berbagai upaya pengendalian banjir disusun sesuai dengan inti permasalahannya[6][7]. Secara umum, pengendalian banjir dilakukan dengan pengurangan debit yang harus dialirkan serta peningkatan kapasitas sungai. Pengurangan debit dilakukan dengan membuat tampungan air sedangkan peningkatan kapasitas sungai dapat dilakukan dengan normalisasi sungai. Selain itu, perbaikan tata guna lahan hingga pembangunan/perbaikan insfrastruktur pelengkap juga dapat dilakukan sebagai upaya pengendalian banjir[8].

Pengelolaan sumber daya air dengan baik akan meminimalisir potensi bencana yang diakibatkan oleh air [9]. Hal tersebut juga akan berdampak pada kesinambungan dan kelestarian lingkungan hidup [10]. Pengelolaan sumber daya air dapat dilakukan dengan pembuatan infrastruktur bangunan air seperti bendung, embung, bendungan[11][12][13]. Bendung merupakan salah satu bangunan air yang berfungsi untuk meninggikan muka air sungai dan mengarahkan atau mengalihkan sebagian air ke tepi kanan sungai dan tepi kiri sungai dengan cara mengalirkan ke saluran melalui bangunan jaringan. Konstruksi bendung perlu direncanakan dengan tepat untuk menjamin berfungsinya bangunan tersebut dengan tepat [14][15].

Sungai Bruno merupakan salah satu sungai yang berada di Kabupaten Kediri [16]. Sungai Bruno termasuk salah satu anak sungai Brantas dengan debit yang cukup besar, dengan lebar sungai mencapai $4 \mathrm{~m}$. Sungai Bruno sering mengalami banjir pada musim penghujan, meski luapannya tidak mencapai permukiman warga. Namun sudah beberapa tanggul di sungai Bruno jebol karena tidak mampu menampung debit dari sungai Bruno. Karakteristik yang demikian cukup berpotensi untuk menjadi penyebab banjir. Tujuan dari penelitian ini yaitu, melakukan pengendalian banjir dengan pembangunan konstruksi bendung pada Sungai Bruno Kediri. Sehingga, muka air sungai dapat ditinggikan dan dapat dialihkan ke tepi kanan maupun kiri sungai.

\section{Metodologi Penelitian}

Penelitian dilakukan pada daerah aliran sungai (DAS) sungai Bruno, Semen, Kabupaten Kediri. Dilakukan perencanaan konstruksi bendung sebagai upaya untuk mengendalikan banjir pada sungai tersebut. Perhitungan anlisa hidrologi serta hidolika dilakukan hingga didapatkan komponen konstruksi bendung. Analisa hidrologi meliputi perhitungan curah hujan, uji kecocokan serta banjir rencana[17]. Sedangkan analisa hidrolika meliputi perhitungan dimensi bendung. Beberapa data yang diperlukan dalam melakukan 
perencanaan, seperti data tata gula lahan (land use), daerah yang memiliki tangkapan air, data topografi, serta dan data curah hujan dikumpulkan. Data yang telah didapatkan kemudian diolah dengan menggunakan beberapa metode dengan uraian sebagai berikut:

\subsection{Analisa Curah Hujan}

Curah hujan pada suatu daerah merupakan salah satu faktor yang menentukan besarnya debit banjir yang terjadi pada suatu wilayah [18][19]. Data curah hujan diperhitungkan untuk memperkirakan debit banjir rencana. Data curah hujan pada stasiun kanyoran diuraikan sebagai berikut

Tabel 1. Data Curah Hujan

\begin{tabular}{lcccccccccc}
\hline \multirow{2}{*}{ Bulan } & \multicolumn{10}{c}{ Data Curah Hujan Tahunan $(\mathbf{m m})$} \\
\cline { 2 - 10 } & $\mathbf{2 0 1 0}$ & $\mathbf{2 0 1 1}$ & $\mathbf{2 0 1 2}$ & $\mathbf{2 0 1 3}$ & $\mathbf{2 0 1 4}$ & $\mathbf{2 0 1 5}$ & $\mathbf{2 0 1 6}$ & $\mathbf{2 0 1 7}$ & $\mathbf{2 0 1 8}$ & $\mathbf{2 0 1 9}$ \\
\hline Januari & 400 & 370 & 361 & 440 & 269 & 226 & 289 & 348 & 423 & 395 \\
Februari & 347 & 221 & 220 & 344 & 235 & 292 & 401 & 306 & 397 & 375 \\
Maret & 370 & 338 & 205 & 241 & 143 & 357 & 271 & 310 & 378 & 315 \\
April & 273 & 242 & 186 & 258 & 150 & 264 & 145 & 268 & 417 & 417 \\
Mei & 255 & 164 & 63 & 179 & 142 & 73 & 199 & 81 & 197 & 210 \\
Juni & 1114 & 4 & 8 & 230 & 63 & 0 & 148 & 47 & 8 & 7 \\
Juli & 117 & 2 & 0 & 83 & 12 & 0 & 68 & 22 & 0 & 0 \\
Agustus & 47 & 0 & 0 & 0 & 2 & 0 & 68 & 0 & 0 & 0 \\
September & 181 & 0 & 0 & 0 & 0 & 0 & 119 & 15 & 75 & 112 \\
Oktober & 207 & 17 & 33 & 33 & 3 & 1 & 192 & 53 & 187 & 215 \\
November & 311 & 150 & 120 & 261 & 156 & 81 & 341 & 268 & 255 & 356 \\
Desember & 362 & 207 & 282 & 335 & 246 & 250 & 260 & 286 & 467 & 487 \\
Jumlah & 3984 & 1715 & 1478 & 2404 & 1421 & 1544 & 2501 & 2004 & 2804 & 2889 \\
\hline
\end{tabular}

Sumber. BPS Kab. Kediri.

Pada analisa curah hujan, dilakukan perhitungan curah hujan maksimum dengan metode poligon thiesen. Dari data hujan yang diperoleh dari stasiun hujan perlu dilakukan analisis frekuensi dan kemungkinan terjadinya serta dilakukan perhitungan distribusi hujan dengan menggunakan Metode Gumbel I, Metode Log Normal dan Log Pearson III [20].

\subsection{Intensitas Hujan Rencana}

Intensitas Hujan Rencana adalah suatu tingginya curah hujan yang terjadi dalam kurun waktu tertentu[21][22]. Perhitungan Intensitas hujan rencana ini menggunakan metode Mononobe yang merupakan sebuah variasi dari persamaan - persamaan curah hujan jangka pendek[23]. Persamaannya sebagai berikut : 


$$
\begin{array}{ll}
I & =\frac{R_{24}}{24} \times\left[\frac{24}{t}\right]^{2 / 3} \\
\mathrm{I} & =\text { Intensitas curah hujan }(\mathrm{mm} / \mathrm{jam}) \\
\mathrm{t} & =\text { Lamanya curah hujan }(\mathrm{jam}) \\
\mathrm{R}_{24} & =\text { Curah hujan maksimum dalam 24 Jam }(\mathrm{mm})
\end{array}
$$

\subsection{Debit Banjir Rencana}

Debit banji rencana digunakan sebagai dasar perhitungan menentukan volume tampungan dari suatu bangunan di sungai. Terdapat beberapa metode perhitungan debit banjir, yaitu metode Rasional, metode Der Weduwen, dan metode Hasper. [24][25]. Untuk melakukan perhitungan debit rencana adalah debit aliran sungai Bruno, dengan Q rencana 10, 15, 25 , dan 50 tahun.

Persamaan matematik Metode Rasional adalah sebagai berikut :

$Q \quad=0,278 . C \cdot I \cdot A$

dimana :

$\mathrm{Q}=$ Debit $(\mathrm{m} 3 /$ detik $)$

$0,278=$ Konstanta, digunakan jika satuan luas daerah menggunakan $\mathrm{km}^{2}$

$\mathrm{C}=$ Koefisien aliran

I $\quad=$ Intensitas curah hujan selama waktu konsentrasi ( $\mathrm{mm} / \mathrm{jam})$

A $\quad=$ Luas daerah aliran $\left(\mathrm{km}^{2}\right)$

\subsection{Panjang Mercu Bendung}

Panjang mercu bendung yaitu jarak antara pangkal-pangkalnya (abutment), sebaiknya sama dengan lebar rata-rata sungai pada bagian yang stabil. Panjang mercu bendung efektif dapat dihitung dengan rumus sebagai berikut :

$B e=B b-20 \% \Sigma b-\Sigma t$

$B e=B b-2(n k p+k a) H$

Keterangan :

$\mathrm{Be}=$ panjang mercu efektif $(\mathrm{m}) \quad \mathrm{n} \quad=$ jumlah pilar pembilas dan pilar jembatan

$\mathrm{Bb}=$ panjang mercu bruto $(\mathrm{m}) \quad \mathrm{kp} \quad=$ koefesien kontraksi pilar

$\Sigma \mathrm{b}=$ jumlah lebar pembilas $\quad \mathrm{ka} \quad=$ koefesien kontraksi pangkal bendung

$\Sigma \mathrm{t}=$ jumalh pilar-pilar pembilas

$\mathrm{H}$ = tinggi energy (m), yaitu $\mathrm{h}+\mathrm{k}$;

$\mathrm{h} \quad=$ tinggi air; $\mathrm{k}=\mathrm{v} 2 / 2 \mathrm{~g}$ 


\subsection{Tinggi Muka Air diatas Bendung}

Tinggi muka air di atas mercu dapat dihitung dengan persamaan tinggi energi-debit, untuk ambang bulat dan pengontrol segi empat, yaitu :

$$
Q d=C d x \frac{2}{3} \text { beff } x \sqrt{2 / 3 g} x H^{\frac{3}{2}}
$$

Keterangan :

Qd = debit (m3/det)

$\mathrm{Cd}=$ koefisien debit $(\mathrm{Cd}=\mathrm{C} 0 . \mathrm{C} 1 . \mathrm{C} 2)$

g = percepatan gravitasi $\left(\mathrm{m} / \operatorname{det}^{2}\right)$

beff $=$ panjang mercu efektif $(\mathrm{m})$

$\mathrm{H} \quad=$ tinggi energi di atas mercu (m)

\section{Pembahasan}

\subsection{Analisa Hidrologi}

Analisa hidrologi meliputi perhitunga curah hujan, uji kecocokan serta banjir rencana dengan uraia sebagai berikut:

\section{1) Curah Hujan}

Perhitungan curah hujan maksimum didasarkan pada data curah hujan yang didapatkan dari stasiun Hujan Kanyuran dalam 10 tahun terakhir (2010-2019). Hasil perhitungan curah hujan maksimum diuraikan sebagai berikut:

Tabel 2. Perhitungan Curah hujan maksimum

\begin{tabular}{cc}
\hline Tahun & Curah Hujan Maksimum (mm) \\
\hline 2010 & 400 \\
2011 & 370 \\
2012 & 361 \\
2013 & 440 \\
2014 & 269 \\
2015 & 357 \\
2016 & 401 \\
2017 & 400 \\
2018 & 415 \\
2019 & 487 \\
\hline
\end{tabular}

Sumber. Hasil Analisa

Dari Tabel 2. Dapat dilihat bahwa curah hujan maksimum pada tahun 2010 higga 2019 berada pada rentang 200-500 mm . curah hujan tertinggi terjadi pada tahun 2019 sebesar 487 mm. 


\section{2) Frekuensi Debit Banjir}

Dari data hujan yang diperoleh dari stasiun hujan perlu dilakukan analisis frekuensi dan kemungkinan terjadinya. Terdapat parameter statistik yang digunakan dalam perhitungan ini, yaitu rata - rata, simpangan baku, koefisien skewness, koefisien variasi, dan koefisin kurtosis

\section{a. Standart Deviasi}

$$
\begin{aligned}
& S d=\sqrt{\frac{\sum\left(X_{i}-\overline{X^{2}}\right)}{n-1}} \\
& S d=\sqrt{\frac{29826}{10-1}} \\
& S d=57,57
\end{aligned}
$$

Didapatkan nilai standart deviasi 57,57

\section{b. Koefisien Skewness (Cs)}

$$
\begin{aligned}
& C s=\frac{\sum_{i=1}^{n}\left\{(X i-\bar{X}\}^{2}\right.}{(n-1)(n-2) S d^{3}} \\
& C s=\frac{10 \times(-783258)}{(10-1)(10-2) 47,75^{3}} \\
& C s=\frac{10 \times(-783258)}{(10-1)(10-2) 190778,20} \\
& C s=-0,570
\end{aligned}
$$

Didapatkan nilai Koefisien Skewness -0,570

\section{c. Pengukuran Kurtosis (Ck)}

$$
\begin{aligned}
& C k=\frac{\frac{1}{n} \sum_{i=1}^{n}\{(X i)-\bar{X}\}^{4}}{S d^{4}} \\
& C k=\frac{\frac{1}{10} 311616630}{57,57^{4}} \\
& C k=2,027
\end{aligned}
$$

Didapatkan nilai Pengukuran Kurtosis 2,027 


\section{d. Koefisien Variasi (Cv)}

$$
\begin{aligned}
& C v=\frac{S d}{\bar{x}} \\
& C v=\frac{57,57}{390} \\
& C v=0,148
\end{aligned}
$$

Didapatkan nilai Koefisien Variasi 0,148

\section{3) Analisa Jenis Sebaran}

Analisis jenis sebaran dilakukan dengan melakukan perhitungan curah hujan rencana menggunakan metode Normal, Matode Gumbel, Metode Log Person III dan Metode Log

\begin{tabular}{|c|c|c|c|c|}
\hline No & Periode & Metode Gumbel I & $\begin{array}{c}\text { Metode Log } \\
\text { Person III }\end{array}$ & $\begin{array}{c}\text { Metode Log } \\
\text { Normal }\end{array}$ \\
\hline 1 & 2 & 382,20 & 228,9791575 & 392,1614814 \\
\hline 2 & 5 & 450,91 & 371,4130597 & 441,115347 \\
\hline 3 & 10 & 496,39 & 472,8890116 & 407,3796411 \\
\hline 4 & 25 & 539,46 & 607,1008696 & 483,2215473 \\
\hline 5 & 50 & 553,88 & 710,2246907 & 515,1566904 \\
\hline 6 & 100 & 596,52 & 815,2730113 & 0 \\
\hline 7 & 200 & 638,85 & 923,2020689 & - \\
\hline 8 & 1000 & 681,04 & 1185,218445 & - \\
\hline
\end{tabular}
Normal. Hasil perhitungan diuraikan sebagai berikut :

Tabel 3. Hasil Perhitungan Analisa Jenis Sebaran.

Sumber. Hasil Analisa

Tabel 3. menunjukan jenis sebaran dengan bebagai metode, dippilih metode Metode Gumbel.

\section{4) Analisa Intensitas Hujan Rencana}

Perhitungan Intensitas hujan rencana ini menggunakan metode Mononobe dengan hasil sebagai berikut: : 
Tabel 4. Perhitungan Insensitas Hujan berdasarkan waktu lamanya (t)

\begin{tabular}{|c|c|c|c|c|c|c|c|c|}
\hline \multirow{2}{*}{$\mathbf{t}(\mathbf{j a m})$} & R2 & R5 & R10 & $\mathbf{R 2 5}$ & R50 & R100 & R200 & R1000 \\
\hline & 382,20 & 450,91 & 496,39 & 539,46 & 553,88 & 596,5235 & 638,85 & 681,04 \\
\hline 1 & 132,501 & 156,321 & 172,090 & 187,020 & 192,020 & 206,803 & 221,477 & 236,103 \\
\hline 2 & 83,470 & 98,476 & 108,410 & 117,815 & 120,965 & 130,278 & 139,522 & 148,735 \\
\hline 3 & 63,700 & 75,151 & 82,732 & 89,910 & 92,314 & 99,421 & 106,475 & 113,506 \\
\hline 4 & 52,583 & 62,036 & 68,294 & 74,219 & 76,203 & 82,070 & 87,893 & 93,697 \\
\hline 5 & 45,315 & 53,461 & 58,854 & 63,960 & 65,670 & 70,726 & 75,744 & 80,746 \\
\hline 6 & 40,128 & 47,342 & 52,118 & 56,640 & 58,154 & 62,631 & 67,075 & 71,504 \\
\hline 7 & 36,209 & 42,719 & 47,028 & 51,108 & 52,474 & 56,514 & 60,524 & 64,521 \\
\hline 8 & 33,125 & 39,080 & 43,022 & 46,755 & 48,005 & 51,701 & 55,369 & 59,026 \\
\hline 9 & 30,624 & 36,129 & 39,773 & 43,224 & 44,380 & 47,796 & 51,188 & 54,568 \\
\hline 10 & 28,546 & 33,678 & 37,076 & 40,292 & 41,369 & 44,554 & 47,716 & 50,867 \\
\hline 11 & 26,789 & 31,605 & 34,793 & 37,812 & 38,823 & 41,811 & 44,778 & 47,735 \\
\hline 12 & 25,279 & 29,824 & 32,832 & 35,681 & 36,635 & 39,455 & 42,255 & 45,045 \\
\hline 13 & 23,966 & 28,274 & 31,126 & 33,827 & 34,731 & 37,405 & 40,059 & 42,704 \\
\hline 14 & 22,810 & 26,911 & 29,626 & 32,196 & 33,057 & 35,602 & 38,128 & 40,646 \\
\hline 15 & 21,785 & 25,701 & 28,294 & 30,749 & 31,571 & 34,001 & 36,414 & 38,819 \\
\hline 16 & 20,868 & 24,619 & 27,102 & 29,454 & 30,241 & 32,569 & 34,880 & 37,184 \\
\hline 17 & 20,041 & 23,644 & 26,029 & 28,287 & 29,043 & 31,279 & 33,499 & 35,711 \\
\hline 18 & 19,292 & 22,760 & 25,056 & 27,230 & 27,957 & 30,110 & 32,246 & 34,376 \\
\hline 19 & 18,609 & 21,954 & 24,169 & 26,266 & 26,968 & 29,044 & 31,105 & 33,159 \\
\hline 20 & 17,983 & 21,216 & 23,356 & 25,383 & 26,061 & 28,068 & 30,059 & 32,044 \\
\hline 21 & 17,408 & 20,537 & 22,609 & 24,570 & 25,227 & 27,169 & 29,097 & 31,019 \\
\hline 22 & 16,876 & 19,910 & 21,918 & 23,820 & 24,457 & 26,340 & 28,209 & 30,071 \\
\hline 23 & 16,383 & 19,329 & 21,278 & 23,124 & 23,743 & 25,570 & 27,385 & 29,193 \\
\hline 24 & 15,925 & 18,788 & 20,683 & 22,477 & 23,078 & 24,855 & 26,619 & 28,377 \\
\hline Rata - Rata & 34,592 & 40,811 & 44,928 & 48,826 & 50,131 & 53,991 & 57,821 & 61,640 \\
\hline
\end{tabular}

Sumber. Hasil Analisa

Rata - rata dari intensitas hujanlah yang nantinya akan digunakan pada perhitunga debit banjir rencana.

\section{4) Debit Banjir Rencana}

Untuk menghitung atau memperkirakan besarnya debit banjir yang akan terjadi dalam berbagai periode ulang dengan hasil yang baik dapat dilakukan dengan analisis data aliran dari sungai Bruno Hasil perhitungan diuraikan sebagai berikut: 
Tabel 5. Perhitungan Debit Banjir Rencana

\begin{tabular}{cccc}
\hline Periode & Metode Rasional & Metode Weduwen & Metode Haspers \\
\hline 2 & 63,97486894 & 161,1536 & 315,307 \\
5 & 75,47598314 & 190,12507 & 371,992 \\
10 & 83,08961114 & 209,30391 & 409,517 \\
25 & 90,29835609 & 227,46284 & 445,046 \\
50 & 92,71243326 & 233,54393 & 456,944 \\
100 & 99,85014609 & 251,52393 & 492,123 \\
200 & 106,9350922 & 269,37101 & 527,042 \\
1000 & 113,9966992 & 287,1593 & 561,846 \\
\hline
\end{tabular}

Sumber: Hasil Analisa.

Debit banjir rencana diatas kemudian dibandingkan untuk mengetahui selisih. Kemudian debit banjir selisih akan digunakan untuk mengetahui volume tampungan kolam. Yakni debit selisih atau dapat disebut kelebihan debit lalu dikali dari t yang didapat. Berikut adalah perbandingan dari kala ulang perhitungan dan dinas, yakni :

Tabel 6. Debit banjir hujan kala ulang analisa \& data instansi

\begin{tabular}{ccc}
\hline $\begin{array}{c}\text { Periode Ulang } \\
(\text { Tahun })\end{array}$ & $\begin{array}{c}\text { Debit Banjir } \\
\text { Hujan Kala Ulang Analisa } \\
\left(\boldsymbol{m}^{\mathbf{3}} / \boldsymbol{d t k}\right)\end{array}$ & $\begin{array}{c}\text { Debit Banjir } \\
\text { Hujan Kala Ulang } \\
\text { Instansi } \\
\left(\boldsymbol{m}^{3} / \boldsymbol{d} \boldsymbol{t}\right)\end{array}$ \\
\hline 2 & 63,97486894 & 14,57771 \\
5 & 75,47598314 & 17,38479 \\
10 & 83,08961114 & 19,09214 \\
25 & 90,29835609 & 21,09073 \\
50 & 92,71243326 & 22,46833 \\
100 & 99,85014609 & 23,75143 \\
200 & 106,9350922 & 24,95067 \\
1000 & 113,9966992 & 27,45812 \\
\hline
\end{tabular}

Sumber: Hasil Analisa

Karena asumsi perencanaan bangunan Bendung adalah untuk 25 tahun maka kita bandingkan antara debit banjir $\mathrm{R}_{25}$.

Kelebihan Debit = Debit banjir analisa - Debit banjir Instansi

Qlebih

$$
\begin{aligned}
& =90,29835609-21,09073 \\
& =69,20762609 \mathrm{~m}^{3} / \mathrm{dtk} \approx 70 \mathrm{~m}^{3} / \mathrm{dtk}
\end{aligned}
$$




\subsection{Analisa Hidrolika}

\section{1) Perencanaan Hidrolis Bendung}

Elevasi mercu bendung untuk perencanaan bangunan bendung dengan puncak dinding beton $+53,705$ dengan tinggi air maksimum diijinkan dalam saluran $30 \mathrm{~cm}$ dibawah dinding cor beton berarti air paling tinggi dalam saluran adalah +53.405 sedangkan elevasi dasar sungai didapat +50 .

Perhitungan elevasi bendung :
a. Elevasi saluran
$=+53,705 \mathrm{~m}$
b. Kehilangan pada pintu inlet
$=0,10 \mathrm{~m}$
c. Kehilangan pada bangunan ukur
$=0,10 \mathrm{~m}$
d. Kehilangan pada pintu pengambilan
$=0,10 \mathrm{~m}$
e. Kehilangan oleh slope saluran
$=0,10 \mathrm{~m}$
f. Bertambah tinggi air pada saluran suplesi
$=0,10 \mathrm{~m}$
g. Keamanan
$=0,095 \mathrm{~m}$
h. Elevasi mercu bendung
$=+54,3 \mathrm{~m}$
g. Tinggi mercu bendung
= Elevasi mercu - Tinggi mercu bendung $=54,3-50=4,3 \mathrm{~m}$

\section{2) Lebar Efektif Bendung}

Karena adanya pilar dan bangunan pembilas, maka lebar total bendung tidak seluruhnya dapat dimanfaatkan untuk melewatkan debit yang ada. Jadi lebar efektif bendung lebih pendek dari lebar bendung yang sebenarnya.

$\mathrm{Be}=$ lebar efektif bendung $(\mathrm{m})$

$$
\begin{aligned}
& \text { B = lebar bendung }(\mathrm{m}) \quad=30 \mathrm{~m} \\
& \mathrm{~N}=\text { jumlah pilar } \quad=3 \\
& \mathrm{Kp}=\text { koefisien kontraksi pilar } \quad=0,01 \\
& \mathrm{Ka}=\text { koefisien kontraksi pangkal bendung } \quad=0,2 \\
& \mathrm{H} 1 \text { = tinggi energi (m) }
\end{aligned}
$$

\section{Perhitungan :}

$$
\begin{aligned}
\mathrm{B} 1 & =\mathrm{B} 2=10,00 \mathrm{~m} \\
\mathrm{~B} 3 & =1 \mathrm{~m} \\
\mathrm{Be} 1 & =\mathrm{B} 1-2(\mathrm{n} \cdot \mathrm{Kp}+\mathrm{Ka}) \cdot \mathrm{H} 1 \\
& =10,00-2(1 * 0,01+0,2) \mathrm{H} 1 \\
& =10,00-0,42 \mathrm{H} 1
\end{aligned}
$$




$$
\begin{aligned}
\mathrm{Be} 2 & =\mathrm{B} 2-2(\mathrm{n} \cdot \mathrm{Kp}+\mathrm{Ka}) \cdot \mathrm{H} 1 \\
& =10,00-2(2 * 0,01) \mathrm{H} 1 \\
& =10,00-0,04 \mathrm{H} 1 \\
\mathrm{Be} 3 & =\mathrm{B} 2-2(\mathrm{n} \cdot \mathrm{Kp}+\mathrm{Ka}) \cdot \mathrm{H} 1 \\
& =10,17-2(2 * 0,01) \mathrm{H} 1 \\
& =10,17-0,04 \mathrm{H} 1 \\
\mathrm{Bs} & =0,80 * 1=0,8 \mathrm{~m} \\
\mathrm{Be} & =\mathrm{Be} 1+\mathrm{Be} 2+\mathrm{Bisa} \\
& =(10,00-0,42 \mathrm{H} 1)+2 *(10,00-0,04 \mathrm{H} 1)+0,8 \\
& =30,8-0,5 \mathrm{H} 1
\end{aligned}
$$

\section{3) Tinggi Muka Air Banjir di Atas Mercu Bendung}

Perhitungan tinggi muka air banjir di atas mercu menggunakan persamaan debit bendung dengan mercu bulat :

$\mathrm{Q}=70 \mathrm{~m} 3 / \mathrm{dtk}$

$\mathrm{Cd}=$ Koefisien debit $(\mathrm{Cd}=\mathrm{C} 0 . \mathrm{C} 1 . \mathrm{C} 2)$

Direncanakan $\mathrm{p} / \mathrm{H} 1 \geq 1,5$ dan $\mathrm{r}=0.5 \mathrm{H} 1$, maka didapat $\mathrm{H} 1 / \mathrm{r}=2$, dengan didapat nilai

$\mathrm{C} 0=1.33$. Dimisalkan besar $\mathrm{C} 1=1$ dan $\mathrm{C} 2=1$

$g \quad=9,8 \mathrm{~m} / \mathrm{dtk} 2$

$B e=30,8-0,5 \mathrm{H} 1$

$H 1$ = Tinggi energi diatas mercu $(\mathrm{m})$

Perhitungan :

$$
\begin{aligned}
70,0 & =1,33 * \frac{2}{3} * \sqrt{\frac{2}{3}} * 9,8 *(30,80,5 \mathrm{H} 1) * H_{1}^{1,5} \\
& =0,867 \times \frac{2^{\frac{1}{2}}}{3} \times 9,8 \times 30,8 H_{1}^{1,5}-0,5 H_{1}^{2,5} \\
& =4,005 \times 30,8 H_{1}^{1,5}-0,5 H_{1}^{2,5} \\
17,14 & =30,8 H_{1}^{1,5}-0,5 H_{1}^{2,5}
\end{aligned}
$$

Dengan cara coba-coba diperoleh $\mathrm{H} 1 \quad=0,7 \mathrm{~m}$

$\mathrm{Be}$

$$
=30,8-0,5 * 0,7=30,45 \mathrm{~m}
$$

Dari hasil perhitungan di atas maka dapat ditentukan elevasi muka air banjir dan tinggi air di atas mercu yaitu :

Elevasi muka air banjir $=$ elevasi mercu $+\mathrm{H} 1=+54,3+0,7=+55$

Untuk menentukan tinggi air di atas mercu dapat dicari dengan persamaan: 
$\mathrm{Hd}=\mathrm{H} 1-\mathrm{k}$

Dimana :

$$
\begin{aligned}
\mathrm{K} & =\frac{v^{2}}{2 g} \text { dengan } \mathrm{v}=\frac{Q}{B_{e * H_{1}}}=\frac{70}{30,45 * 0,7}=3,285 \mathrm{~m} / \mathrm{dtk} \\
\mathrm{K} & =\frac{3,285^{2}}{2 * 9,8} 0,55 \mathrm{~m}
\end{aligned}
$$

Jadi tinggi air di atas mercu adalah : $\mathrm{Hd}=0,7-0,55=0,15 \mathrm{~m}$

\section{4) Tinggi Muka Air Banjir di Hilir Bendung}

Diketahui :

Debit banjir (Q)

Lebar rata-rata sungai

Kemiringan sungai (Is)

$\gamma B$ (koefisien Bazin)

Rumus Chezy :

$A=(b+m h) h$

$\mathrm{V}=\mathrm{c} \cdot \sqrt{R \cdot I}$

$\mathrm{C}=\frac{87}{1+\frac{Y B}{\sqrt{R}}}$

$\mathrm{P}=\mathrm{b}+2 \mathrm{~h} \sqrt{m^{2}}+1$

$\mathrm{R}=\frac{A}{P}$

$\mathrm{Q}=\mathrm{A} * \mathrm{~V}$

Perhitungan :

$$
\begin{aligned}
\mathrm{A} & =(\mathrm{b}+\mathrm{m} \mathrm{h}) \mathrm{h} \\
& =\left(30+0.5^{*} \mathrm{~h}\right) \mathrm{h} \\
& =30 \mathrm{~h}+0,5 h^{2} \\
\mathrm{P} & =\mathrm{b}+2 \mathrm{~h} \sqrt{m^{2}}+1 \\
& =30+2 * \mathrm{~h} \sqrt{0,5^{2}}+1 \\
& =30+2.236 \mathrm{~h} \\
\mathrm{R} & =\frac{A}{P}=\frac{30 h+0,5 h 2}{30+2.236 h} \\
\mathrm{c} & =\frac{87}{1+\frac{1,5}{\sqrt{\frac{30 h+0,5 h^{2}}{30+2,236 h}}}}
\end{aligned}
$$




$$
\begin{aligned}
\mathrm{V} & =\mathrm{c} \cdot \sqrt{R . I} \\
& =\frac{87}{1+\frac{1,5}{\sqrt{\frac{30 h+0,5 h^{2}}{30+2,236 h}}}} \sqrt{\frac{30 h+0,5 h^{2}}{30+2,236 \mathrm{~h}}} * 0,001 \\
\mathrm{Q} & =\mathrm{A} * \mathrm{~V}
\end{aligned}
$$

didapat $\mathrm{h}=1,56 \mathrm{~m}$, maka :

Elevasi dasar sungai

$$
=+50
$$

Elevasi muka air di hilir bendung $=+50+1,56$

$$
=+51,56 \mathrm{~m}
$$

\section{Kesimpulan dan Saran}

\subsection{Kesimpulan}

Dari hasil perencanaan yang telah dilakukan dapat disimpulkan bahwa

1) Kelebihan debit banjir selisih antara perhitungan dan data dinas terkait pada kala hujan 25 tahun didapatkan yaitu $69,20762609 \mathrm{~m}^{3} / \mathrm{dtk} . \approx 70 \mathrm{~m}^{3} / \mathrm{dtk}$

2) Dari perencanaan bendung sebagai sarana untuk mengendalikan debit banjir didapatkan Elevasi mercu bendung $(+54,3)$, Elevasi dasar sungai (+50), Tinggi mercu bendung (4,3m), debit banjir (Q)(70 m3/dtk), lebar bendung (30 m), hilir bendung (1,56), Elevasi dasar sungai (+50), Elevasi muka air di hilir bendung (+51,56 m)

\section{Ucapan Terima Kasih}

Peneliti mendukung Universitas Kadiri, khususnya kepada Fakultas Teknik yang telah memberikan kesempatan untuk melakukan penelitian dan penyusunan laporan. 


\section{Daftar Pustaka}

[1] F. M. Fan, W. Collischonn, K. J. Quiroz, M. V. Sorribas, D. C. Buarque, and V. A. Siqueira, "Flood forecasting on the Tocantins River using ensemble rainfall forecasts and real-time satellite rainfall estimates," J. Flood Risk Manag., vol. 9, no. 3, pp. 278-288, 2016, doi: $10.1111 /$ jfr3.12177.

[2] R. A. Mel, D. P. Viero, L. Carniello, and L. D’Alpaos, "Optimal floodgate operation for river flood management: The case study of Padova (Italy)," J. Hydrol. Reg. Stud., vol. 30, no. June, p. 100702, 2020, doi: 10.1016/j.ejrh.2020.100702.

[3] A. Gunarto, F. Nursandah, M. Zaenuri, N. A. Affandy, U. Kadiri, and U. I. Lamongan, "Perencanaan Sistem Drainase Ruas Jalan Kuncir - Sawahan Kabupaten Nganjuk," UKaRsT, vol. 1, no. 2, pp. 156-164, 2017.

[4] S. M. H. Shah, Z. Mustaffa, F. Y. Teo, M. A. H. Imam, K. W. Yusof, and E. H. H. Al-Qadami, "A review of the flood hazard and risk management in the South Asian Region, particularly Pakistan,” Sci. African, vol. 10, p. e00651, 2020, doi: 10.1016/j.sciaf.2020.e00651.

[5] N. W. Arnell and S. N. Gosling, "The impacts of climate change on river flood risk at the global scale," Clim. Change, vol. 134, no. 3, pp. 387-401, 2016, doi: 10.1007/s10584-014-1084-5.

[6] A. D. Wicaksono, E. Hidayah, and R. U. A. Wicaksono, "Flood Vulnerability Assessment of Kali Welang Floodplain by Using Analytic Hierarchy Process Based Methods," Ukarst, vol. 5, no. 1, pp. 95-109, 2021, doi: 10.1016/j.gloenvcha.2006.03.008.

[7] A. Herison, Y. Romdania, O. T. Purwadi, and R. Effendi, "Kajian Penggunaan Metode Empiris dalam Menentukan Debit Banjir Rancangan pada Perencanaan Drainase (Review)," J. Apl. Tek. Sipil, vol. 16, no. 2, p. 77, 2018, doi: 10.12962/j2579-891x.v16i2.3819.

[8] J. Teng, A. J. Jakeman, J. Vaze, B. F. W. Croke, D. Dutta, and S. Kim, "Flood inundation modelling: A review of methods, recent advances and uncertainty analysis," Environ. Model. Softw., vol. 90, pp. 201-216, 2017, doi: 10.1016/j.envsoft.2017.01.006.

[9] R. Nakamura and Y. Shimatani, "Extreme-flood control operation of dams in Japan," J. Hydrol. Reg. Stud., vol. 35, no. September 2020, p. 100821, 2021, doi: 10.1016/j.ejrh.2021.100821.

[10] B. Grizzetti, D. Lanzanova, C. Liquete, A. Reynaud, and A. C. Cardoso, "Assessing water ecosystem services for water resource management," Environ. Sci. Policy, vol. 61, pp. 194-203, 2016, doi: 10.1016/j.envsci.2016.04.008.

[11] G. H. J. P. September, E. Hidayah, “Assessment and Optimization of Water Division Pattern in Sampean Baru Irrigation Area," UKaRsT, vol. 5, no. 1, 2021.

[12] J. Yazdi, M. Sabbaghian Moghaddam, and B. Saghafian, "Optimal Design of Check Dams in Mountainous Watersheds for Flood Mitigation," Water Resour. Manag., vol. 32, no. 14, pp. 4793-4811, 2018, doi: 10.1007/s11269-018-2084-4.

[13] H. M. Tu and H. M. Chen, "Effects of flood and flood-control engineering on morbidity," Int. J. 
[14] O. Ari Swenda, A. Ridwan, and S. Winarto, "Analisa Kebutuhan Air Baku Berdasarkan Mata Air Sungai Bayong ( Study Kasus Di Kec. Bendungan Kab. Trenggalek ),” J. Manaj. Teknol. Tek. Sipil, vol. 2, no. 1, p. 51, 2019, doi: 10.30737/jurmateks.v2i1.391.

[15] P. I. Purwanto, P. T. Juwono, and R. Asmaranto, "Analisa Keruntuhan Bendungan Tugu Kabupaten Trenggalek," J. Tek. Pengair., vol. 8, no. 2, pp. 222-230, 2017, doi: 10.21776/ub.pengairan.2017.008.02.8.

[16] C. Yohana, D. Griandini, and S. Muzambeq, "Penerapan Pembuatan Teknik Lubang Biopori Resapan Sebagai Upaya Pengendalian Banjir," J. Pemberdaya. Masy. Madani, vol. 1, no. 2, pp. 296-308, 2017, doi: 10.21009/jpmm.001.2.10.

[17] D. A. D. Nusantara, "Evaluasi Kapasitas Saluran Drainase di Catchment Area Sub Sistem Bendul Merisi Kota Surabaya," U KaRsT, vol. 4, no. 1, 2020.

[18] R. D. Prasetyo, Y. Cahyo, and A. Ridwan, "Analisa Perencanaan Sistem Drainase Dalam Upaya Penanggulangan Banjir Di Kecamatan Gandusari Kabupaten Trenggalek,” J. Manaj. Teknol. Tek. Sipil, vol. 2, no. 1, p. 131, 2019, doi: 10.30737/jurmateks.v2i1.405.

[19] I. M. Brodie, "Rational Monte Carlo method for flood frequency analysis in urban catchments," J. Hydrol., vol. 486, no. January 2011, pp. 306-314, 2013, doi: 10.1016/j.jhydrol.2013.01.039.

[20] Romadhon, M. Zaenuri, and H. Pratikno, "Perencanaan Sistem Drainase Dan Trotoar ( Study Kasus : Lingkungan Kelurahan Banjaran Kota Kediri )," U KaRsT, vol. 3, no. 1, pp. 66-74, 2019.

[21] A. Saad Al-Wagdany, "Intensity-duration-frequency curve derivation from different rain gauge records," J. King Saud Univ. - Sci., vol. 32, no. 8, pp. 3421-3431, 2020, doi: 10.1016/j.jksus.2020.09.028.

[22] S. Z and Muhammad Cornal Rifai, "Analisis Curah Hujan Untuk Pendugaan Debit Banjir Pada Das Batang Arau Padang,” Menara Ilmu, vol. VII, no. 3, pp. 134-144, 2018.

[23] N. K. Agustin, A. Ridwan, and S. Sudjati, "Analisa Sistem Jaringan Drainase (Studi Kasus : Desa Sumengko, Kecamatan Sukomoro, Kabupaten Nganjuk)," J. Manaj. Teknol. Tek. Sipil, vol. 2, no. 2, p. 245, 2019, doi: 10.30737/jurmateks.v2i2.516.

[24] J. Sutikno, A. Ridwan, and Y. C. S. Purnomo, “Analisa Stabilitas Checkdam Pabyongan Desa Mulyosari Kecamatan Pagerwojo Kabupaten Tulungagung,” J. Manaj. Teknol. Tek. Sipil, vol. 1, no. 1, pp. 66-75, 2018, doi: 10.30737/jurmateks.v1i1.141.

[25] W. T. Cahyono, Y. C. S. Purnomo, and S. Winarto, "Studi Efisiensi Pemberian Air Irigasi Pada Desa Grompol Kecamatan Gampengrejo Kabupaten Kediri (Studi kasus di saluran sekunder BPP I Gampengrejo Kediri),” J. Manaj. Teknol. Tek. Sipil, 2018, doi: 10.30737/jurmateks.v1i1.137. 